\title{
Synthesis and evaluation of antibacterial and antioxidative activities of carbazole derivatives
}

\author{
Kestutis Dabrovolskas ${ }^{1}$, \\ Ilona Jonuskiene ${ }^{2}$, \\ Simona Sutkuviene ${ }^{3,4}$, \\ Dalius Gudeika ${ }^{*}$ \\ ${ }^{1}$ Department of Polymer Chemistry \\ and Technology, \\ Kaunas University of Technology, \\ 19 Radvilenu Street, \\ 50254 Kaunas, Lithuania \\ ${ }^{2}$ Department of Organic Chemistry, \\ Kaunas University of Technology, \\ 19 Radvilenu Street, \\ 50254 Kaunas, Lithuania \\ ${ }^{3}$ Department of Biochemistry, \\ Faculty of Medicine, \\ Lithuanian University of Health Sciences, \\ 18 Tilžès Street, \\ 47181 Kaunas, Lithuania \\ ${ }^{4}$ Department of Biochemistry, \\ Faculty of Natural Sciences, \\ Vytautas Magnus University, \\ 8 Vileikos Street, \\ 44404 Kaunas, Lithuania
}

Seven compounds were synthesized by known methods, and their antibacterial activity was evaluated against Bacillus subtilis and Escherichia coli using a disk diffusion method. Antioxidative activity was evaluated using free 1,1-diphenyl-2-picryl-hydrazyl radical scavenging assay and ferric reducing antioxidant power methods. The disk diffusion method revealed that 6 out of 7 tested compounds showed antibacterial activity against tested strains, they inhibited the growth of bacteria at various concentrations, from 31.25 to $250 \mu \mathrm{g} / \mathrm{ml}$. 3-Cyano- $9 H$-carbazole, 3-iodo- $9 H$ carbazole and 3,6-diiodo-9H-carbazole showed a stronger antibacterial activity against Bacillus subtilis compared to the reference drug amoxicillin. 1,3,6-Tribromo-9H-carbazole showed a stronger activity against Escherichia coli. All tested compounds showed a weak antioxidative activity by the 1,1-diphenyl-2-picryl-hydrazyl radical scavenging assay and ferric reducing antioxidant power assay methods.

Keywords: antibacterial agents, antioxidative activity, carbazole, disk diffusion method, Bacillus subtilis and Escherichia coli

\section{INTRODUCTION}

Even though there are many antibacterial agents, multidrug resistant bacteria pose a huge threat to public health and have become one of the biggest health problems in the last decade. Therefore, there is an urgent need to develop and provide

\footnotetext{
* Corresponding author. Email: dalius.gudeika@ktu.lt
}

novel and more potent antibacterial agents to overcome drug resistance [1].

Carbazole and its derivatives are an important type of nitrogen-containing aromatic heterocyclic compounds that can be found in the nature or synthesized by various methods. In nature carbazole is found as an alkaloid that is isolated from various parts of the plant [2]. Such carbazole ring containing alkaloids are carbomycins that 
were first isolated from Streptoverticillium ehimense and showed a good activity against various organisms, which made carbazoles a desirable target for further biological research [3]. Carbazole and its derivatives are extensively used in various chemistry fields such as photoelectrical materials, dyes and supramolecular recognition [4-6]. Also, it is known that natural and synthesized carbazole derivatives have shown good biological activities.

It has been observed that carbazole compounds exhibit multiple mechanisms of antibacterial activity action. One is that carbazole compounds increase membrane permeability by inhibiting specific enzymatic processes. Increased penetration of free radicals violates integrity of bacterial cells [7]. Second, the mechanism of action is that carbazole compounds can interact with bacterial DNA by forming non-covalent interactions with DNA gyrase [8]. Therefore, various $\mathrm{N}$ and $\mathrm{C}$ substituted carbazoles are attractive targets to develop and produce new antibacterial agents with two possible antibacterial mechanisms of action, that could help resolve the drug resistance problem.

Even though scientific and clinical communities made a big step towards understanding how to fight with various bacterial infections, the emergence of multidrug resistant bacteria such as Escherichia coli [9], which remains a frequent cause of various urinary tract, enteric and systemic infections in humans [10], continues to present challenges to human health.

In this work, we have chosen known carbazole compounds with appropriate halogens, cyano and alkyl groups at various carbazole positions to evaluate their antibacterial activities against Gramnegative, Escherichia coli, and compare it to Grampositive, Bacillus subtilis, as possible lead structures for further development and research of antibacterial agents; as well as to evaluate and compare the influence of different substitutes and different carbazole ring positions on antioxidant properties, seeing that there was no published information about antioxidant activities of selected compounds.

\section{EXPERIMENTAL}

\section{Materials and methods}

9H-Carbazole (I), 4,4'-dibromobiphenyl (III), 9-ethyl-9H-carbazole (5) and 1,6-dibromohexane were purchased from Sigma Aldrich.
${ }^{1} \mathrm{H}$ NMR $(300 \mathrm{MHz})$ and ${ }^{13} \mathrm{C}$ NMR $(75 \mathrm{MHz})$ spectra were recorded on a Varian Unity Inova 300 apparatus.

\section{Synthesis}

3-Bromo-9H-carbazole (II). A solution of $\mathrm{N}$-bromosuccinimide (NBS) $(4.48 \mathrm{~g}, 23.92 \mathrm{mmol})$ in $10 \mathrm{~mL}$ DMF was added slowly to a solution of $9 \mathrm{H}$-carbazole (I) $(4 \mathrm{~g}, 0.02392 \mathrm{~mol})$ in dichloromethane $(75 \mathrm{~mL})$ in a two-necked round bottom flask. The reaction mixture was stirred for $3 \mathrm{~h}$ at room temperature. The mixture was extracted with $\mathrm{H}_{2} \mathrm{O}$ and dried over anhydrous $\mathrm{MgSO}_{4}$ for $12 \mathrm{~h}$ and filtered. The excess of the solvent was evaporated and dried under vacuum. The final compound was obtained in $98 \%(5.76 \mathrm{~g})$ as a white solid. M. p. $188-189^{\circ} \mathrm{C} .{ }^{1} \mathrm{H}$ NMR $(300 \mathrm{MHz}$, $\left.\mathrm{CDCl}_{3}\right): \delta 7.25(\mathrm{~m}, 1 \mathrm{H}), 7.31(\mathrm{~d}, J=8.4 \mathrm{~Hz}, 1 \mathrm{H}), 7.43$ (m, $1 \mathrm{H}), 7.5(\mathrm{~d}, J=6.6 \mathrm{~Hz}, 1 \mathrm{H}), 8.0(\mathrm{~d}, J=7.8 \mathrm{~Hz}$, $1 \mathrm{H}), 8.08(\mathrm{~s}, 1 \mathrm{H}), 8.1(\mathrm{~s}, 1 \mathrm{H}), 8.18(\mathrm{~d}, J=4 \mathrm{~Hz}, 1 \mathrm{H})$. ${ }^{13} \mathrm{C}$ NMR $\left(75 \mathrm{MHz}, \mathrm{CDCl}_{3}\right): \delta 139.9,138.1,128.6$, $126.7,125.2,123.4,122.5,120.6,120.0,112.3,112.1$, 110.9 .

3-Cyano-9H-carbazole (1a) [11]. A solution of 3-bromo-9H-carbazole (II) (23.08 g, $94 \mathrm{mmol}$ ) and cuprous cyanide $(9.33 \mathrm{~g}, 0.103 \mathrm{~mol})$ in $N$-methylpyrrolidone $(300 \mathrm{ml})$ was heated at $200^{\circ} \mathrm{C}$ for $5 \mathrm{~h}$. The cooled reaction mixture was poured on to water $(600 \mathrm{ml})$ and the precipitate was filtered off and washed with ethyl acetate $(3 \times 50 \mathrm{ml})$. The filtrate was extracted with ethyl acetate $(3 \times 250 \mathrm{ml})$ and the combined ethyl acetate extracts were washed with water $(150 \mathrm{ml})$ and brine $(150 \mathrm{ml})$, dried using $\mathrm{MgSO}_{4}$ and concentrated in vacuum. The residue was crystallized from heptane and recrystallized from acetonitrile $(70 \mathrm{ml})$ acquiring $7.16 \mathrm{~g}, 40 \%$ of $\mathbf{1 a}$ as a white solid. M. p. $180-181^{\circ} \mathrm{C} .{ }^{1} \mathrm{H}$ NMR (300 MHz, DMSO) $\delta 11.91(\mathrm{~s}, 1 \mathrm{H}), 8.85(\mathrm{~s}, 1 \mathrm{H}), 8.27$ $(\mathrm{d}, J=7.8 \mathrm{~Hz}, 1 \mathrm{H}), 7.78(\mathrm{dd}, J=8.4,1.6 \mathrm{~Hz}, 1 \mathrm{H})$, $7.67(\mathrm{~d}, J=8.4 \mathrm{~Hz}, 1 \mathrm{H}), 7.61(\mathrm{~d}, J=8.0 \mathrm{~Hz}, 1 \mathrm{H}), 7.56$ $(\mathrm{t}, J=7.2 \mathrm{~Hz}, 1 \mathrm{H}), 7.33(\mathrm{t}, J=8.0 \mathrm{~Hz}, 1 \mathrm{H}) .{ }^{13} \mathrm{CNMR}$ (75 MHz, DMSO): $\delta 142.6,141.2,129.5,127.9,126.5$, $123.6,122.5,121.9,121.5,120.8,113.0,112.5,101.1$.

4,4'-Dibromo-2-nitrobiphenyl (IV). 4,4'-Dibromobiphenyl (III) (10 g, $32 \mathrm{mmol})$ was dissolved in glacial acetic acid $(120 \mathrm{~mL})$, and the mixture was stirred and heated to $100^{\circ} \mathrm{C}$ for $24 \mathrm{~h}$. Then, fuming concentrated nitric acid $(95 \%, 40 \mathrm{~mL})$ was added and the resulting mixture was allowed to react for another $30 \mathrm{~min}$. After the reaction, the solution was cooled to room temperature, the crude product 
was filtered. After recrystallization from ethanol, the title compound was obtained in $91 \%$ yield as white crystals. ${ }^{1} \mathrm{H}$ NMR $\left(300 \mathrm{MHz}, \mathrm{CDCl}_{3}\right)$ : $\delta 8.03(\mathrm{~d}, J=1.8 \mathrm{~Hz}, 1 \mathrm{H}), 7.76\left(\mathrm{dd}, J_{1}=8.1 \mathrm{~Hz}\right.$, $\left.J_{2}=1.8 \mathrm{~Hz}, 1 \mathrm{H}\right), 7.54-7.59(\mathrm{~m}, 2 \mathrm{H}), 7.31(\mathrm{~s}, 1 \mathrm{H})$, 7.14-7.18 (m, 2H).

2,7-Dibromo-9H-carbazole (V). $7.8 \mathrm{~g}(22 \mathrm{mmol})$ of 4,4'-dibromo-2-nitrobiphenyl (IV) was dissolved in phosphorous acid triethyl ester $(30 \mathrm{~mL})$ and the mixture was heated to $150^{\circ} \mathrm{C}$ under the protection of argon. The system was allowed to react for $24 \mathrm{~h}$ and a brown solution was obtained. The volatile solvents were then removed by vacuum distillation. The solution left was purified by column chromatography with ethyl acetate/petroleum ether $(10: 1, v / v)$ as the eluent. Finally, a white solid was obtained for 2,7-dibromocarbazole (V) in 48\% yield. ${ }^{1} \mathrm{H}$ NMR $\left(300 \mathrm{MHz}\right.$, acetone- $\left.\mathrm{d}_{6}\right): \delta 10.64(\mathrm{~s}$, $1 \mathrm{H}), 8.09(\mathrm{~d}, J=8.4 \mathrm{~Hz}, 2 \mathrm{H}), 7.75(\mathrm{~d}, J=1.8 \mathrm{~Hz}$, $2 \mathrm{H}), 7.37$ (dd, $J=8.4,1.8 \mathrm{~Hz}, 2 \mathrm{H})$.

2,7-Dicyano-9H-carbazole (1b) [12]. Copper(I) cyanide (CuCN) (14.7 g, $164.3 \mathrm{mmol})$ was added to a stirred solution of 2,7-dibromo-9H-carbazole (IV) (12.28 g, $37.75 \mathrm{mmol})$ in DMF $(150 \mathrm{~mL})$. The solution was maintained at reflux under nitrogen for $9 \mathrm{~h}$. In the reaction mixture $40 \mathrm{~mL}$ of ethylenediamine and $20 \mathrm{~g}$ of $\mathrm{CuCN}$ were used to give a white powder (7.92 g, 96.6\%). M. p. $279-281^{\circ} \mathrm{C} .{ }^{1} \mathrm{H}$ NMR (300 MHz, acetone- $\mathrm{d}_{6}$ ): $\delta 11.3(\mathrm{br}, 1 \mathrm{H}), 8.46-8.43$ (d, 2H), 8.06 (s, 2H), 7.62-7.59 (d, 2H). ${ }^{13} \mathrm{C}$ NMR $\left(75 \mathrm{MHz}\right.$, acetone- $\left.\mathrm{d}_{6}\right): \delta 141.0,126.1,123.4,123.1$, 120.1, 116.8, 110.7 .

3-Iodo-9H-carbazole (2a) [13]. 9H-carbazole (I) (16.7 g, $101 \mathrm{mmol})$ was dissolved in boiling glacial acetic acid $(250 \mathrm{~mL})$ and $\mathrm{KI}(11.73 \mathrm{~g}, 135 \mathrm{mmol})$ was added. The solution was cooled, ground potassium iodate $(23.42 \mathrm{~g}, 150 \mathrm{mmol})$ was added, and the mixture was boiled until it acquired a clear straw-coloured tint $(10 \mathrm{~min})$. The hot solution was decanted from the undissolved potassium iodate, and it was cooled to $45^{\circ} \mathrm{C}$. The faintly brown plates were rapidly filtered off and recrystallized from alcohol, and the solution was allowed to cool to $45^{\circ} \mathrm{C}$. The faintly brown plates were rapidly filtered off and recrystallized from ethanol; the solution was allowed to cool to $45^{\circ} \mathrm{C}$ and filtered, yielding $9.73 \mathrm{~g}$, $47 \%$ of $2 \mathrm{a}$ as a brown solid. M. p. $202^{\circ} \mathrm{C} .{ }^{1} \mathrm{H}$ NMR $\left(300 \mathrm{MHz}, \mathrm{CDCl}_{3}\right): \delta 8.41(\mathrm{~s}, 1 \mathrm{H}), 8.11(\mathrm{~s}, 1 \mathrm{H})$, $8.04(\mathrm{~d}, J=1.7 \mathrm{~Hz}, 1 \mathrm{H}), 7.68(\mathrm{dd}, J=1.7 \mathrm{~Hz}, 1 \mathrm{H})$, 7.42-7.49 (m, 2H), 7.22-7.28 (m, 2H). ${ }^{13} \mathrm{C}$ NMR $\left(75 \mathrm{MHz}, \mathrm{CDCl}_{3}\right): \delta 139.5,138.6,134.1,129.2$, $126.6,125.9,122.1,120.5,119.9,112.6,110.7$.

3,6-Diiodo-9H-carbazole (2b) [13]. To a solution of $9 \mathrm{H}$-carbazole (I) $(5.00 \mathrm{~g}, 30.43 \mathrm{mmol}$ ) in acetic acid $(85 \mathrm{~mL})$ potassium iodide $(6.67 \mathrm{~g}$, $40.17 \mathrm{mmol}$ ) was added. With stirring, potassium iodate $(9.77 \mathrm{~g}, 45.65 \mathrm{mmol}$ ) was slowly added into the mixture and refluxed for $10 \mathrm{~min}$. The reaction mixture was cooled to room temperature, filtered and washed with acetic acid (50 mL) to yield in $96 \%$ $(11.94 \mathrm{~g})$ as pale-yellow powder. M. p. $208-211^{\circ} \mathrm{C}$. ${ }^{1} \mathrm{H} \mathrm{NMR}\left(300 \mathrm{MHz}, \mathrm{CDCl}_{3}\right): \delta 8.30(\mathrm{~d}, J=1.6 \mathrm{~Hz}$, $2 \mathrm{H}), 8.07(\mathrm{~s}, 1 \mathrm{H}), 7.67$ (d, $J=8.8 \mathrm{~Hz}, 1.6 \mathrm{~Hz}, 2 \mathrm{H})$, $7.20(\mathrm{~d}, J=8.4 \mathrm{~Hz}, 2 \mathrm{H}) .{ }^{13} \mathrm{C} \mathrm{NMR}\left(75 \mathrm{MHz}, \mathrm{CDCl}_{3}\right)$ : $\delta 138.4,134.7,129.2,123.4,112.6,82.4$.

1,3,6-Tribromo-9H-carbazole (3) [14]. To a stirred solution of $9 \mathrm{H}$-carbazole (I) $(1 \mathrm{mmol})$ in dichloromethane $(50 \mathrm{~mL})$, containing silica $(10 \mathrm{~g})$, a solution of NBS $(0.890 \mathrm{~g}, 5.0 \mathrm{mmol})$ in dichloromethane $(75 \mathrm{~mL})$ was added dropwise. The reaction mixture was stirred for appropriate time in the absence of light at ambient temperature until TLC indicated that it was complete. The reaction mixture was then filtered, and the silica washed with dichloromethane $(3 \times 15 \mathrm{~mL})$. The combined extracts were washed with water $(100 \mathrm{~mL})$ and the organic layer was dried and evaporated to yield 3 as a white solid in $96 \%$. M. p. $172-173^{\circ} \mathrm{C}$. ${ }^{1} \mathrm{H}$ NMR $\left(300 \mathrm{MHz}\right.$, acetone- $\left.\mathrm{d}_{6}\right): \delta 7.50(\mathrm{~d}, J=8.0 \mathrm{~Hz}, 1 \mathrm{H})$, $7.54(\mathrm{~d}, J=8.0 \mathrm{~Hz}, 1 \mathrm{H}), 7.67(\mathrm{~s}, 1 \mathrm{H}) ; 8.26(\mathrm{~s}, 2 \mathrm{H})$; $10.70(\mathrm{~s}, 1 \mathrm{H}) \cdot{ }^{13} \mathrm{C}$ NMR $\left(75 \mathrm{MHz}\right.$, acetone- $\left.\mathrm{d}_{6}\right): \delta$ 105.19, 112.1, 113.1, 114.2, 123.3, 124.4, 124.8, 125.5, 130.5, 131.1, 138.5, 139.8 .

1,6-Di(3-iodo-9H-carbazolyl)hexane (4) [15]. A mixture containing ( $12 \mathrm{~g}, 41 \mathrm{mmol}$ ) of 3-iodo- $9 \mathrm{H}$ carbazole (2a), (3.9 g, $16 \mathrm{mmol}$ ) of 1,6-dibromohexane, and $(0.4 \mathrm{~g}, 1.2 \mathrm{mmol})$ of $\mathrm{KOH}$ were heated to reflux in $70 \mathrm{~mL}$ of acetone, and then $(1.8 \mathrm{~g}, 32 \mathrm{mmol})$ of powdered potassium hydroxide was added. After refluxing for $12 \mathrm{~h}$, during which time a white precipitate formed, acetone was removed, and the reaction product was dissolved in chloroform. The obtained suspension was filtered, and the solution was washed with water. After removal of the solvent, the product was purified by two crystallizations from acetone to yield $4.7 \mathrm{~g}, 44 \%$ of white crystals. ${ }^{1} \mathrm{H}$ NMR $\left(300 \mathrm{MHz}, \mathrm{CDCl}_{3}\right): \delta 1.24-1.31(\mathrm{~m}, 4 \mathrm{H}), 1.67-1.82$ $(\mathrm{m}, 4 \mathrm{H}), 4.15(\mathrm{t}, J=6.9 \mathrm{~Hz}, 4 \mathrm{H}), 7.04(\mathrm{~d}, J=8.8 \mathrm{~Hz}$, $2 \mathrm{H}), 7.16-7.64(\mathrm{~m}, 8 \mathrm{H}), 7.99(\mathrm{~d}, J=7.8 \mathrm{~Hz}, 2 \mathrm{H})$, $8.35(\mathrm{~s}, 2 \mathrm{H})$. 


\section{Evaluation of antibacterial activity}

Antibacterial activity of the compounds was tested using the disk diffusion method [16]. In this study inhibition of bacterial growth was investigated against Gram-positive bacteria Bacillus subtilis and Gram-negative bacteria Escherichia coli. The solution $(1 \mathrm{mg} / \mathrm{ml})$ of the compounds was prepared in DMSO and then diluted to various concentrations $(31.25-1000 \mu \mathrm{g} / \mathrm{ml})$ in DMSO. Bacterial cultures were cultivated in Petri dishes at $37^{\circ} \mathrm{C}$ for $24 \mathrm{~h}$ on the Luria-Bertani (LB) agar medium [17]. $50 \mu \mathrm{L}$ inoculum containing bacterial cells were spread across the LB agar medium. Sterile filter paper disks were soaked in $25 \mu \mathrm{L}$ of each compound solution, and then the disks were put on the LB agar medium. Amoxicillin and ciprofloxacin were used as positive control, and DMSO was used as the negative control. Petri dishes were incubated aerobically at $37^{\circ} \mathrm{C}$ and examined for zones of inhibition after $24 \mathrm{~h}$. The inhibition zones were measured using a ruler (Fig. 1).

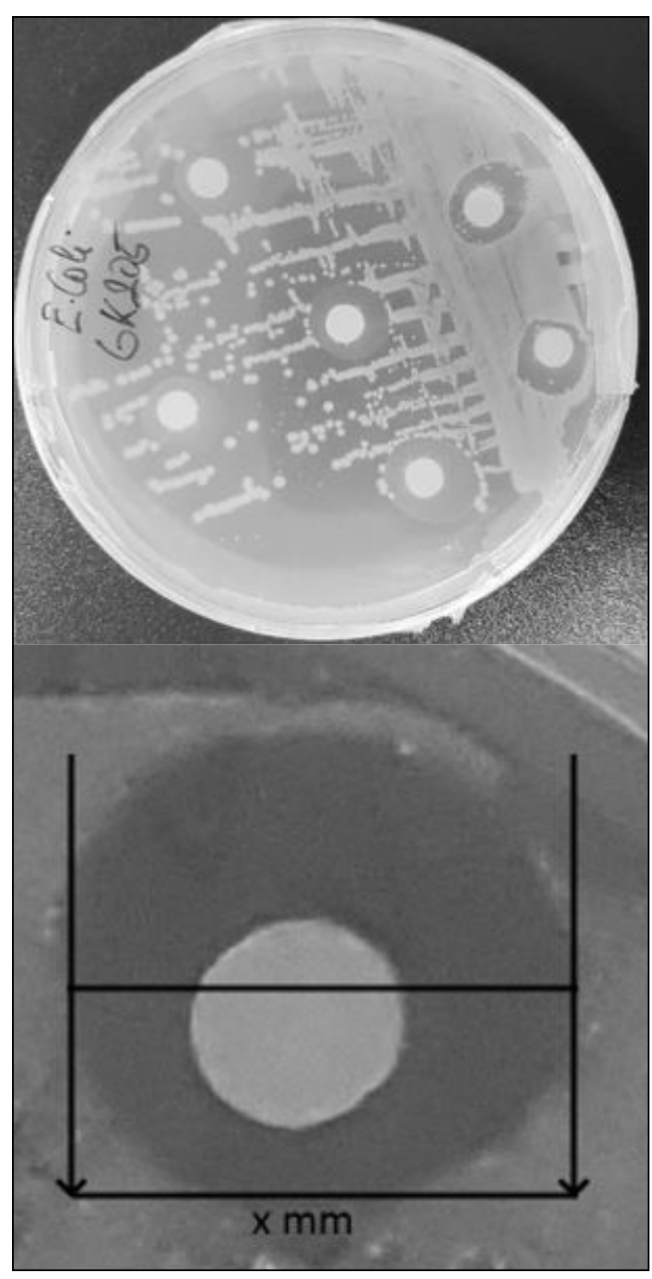

Fig. 1. Top: disk placement onto a Petri dish. Bottom: bacterial growth inhibition zone evaluation

\section{1,1-Diphenyl-2-picrylhydrazyl (DPPH) radical scavenging assay}

The free radical scavenging activity of the compounds was measured by the DPPH method [18]. At first, a solution ( $5 \mathrm{mM}$ ) of the compounds was prepared in DMSO. Then, a $1 \mathrm{mM}$ solution of $\mathrm{DPPH}$ in ethanol was prepared and $1 \mathrm{~mL}$ of this solution was added to the solutions of the selected compounds. The mixture was vigorously stirred and allowed to stand at room temperature. After $20 \mathrm{~min}$, the absorbance of the reaction mixture was measured at $517 \mathrm{~nm}$ with a UV-1280 spectrophotometer (Shmidazu). The activity of DPPH radical scavenging was calculated according to the following equation:

$$
\text { DPPH scavenging effect }(\%)=\frac{\left(A_{b}-A_{a}\right)}{A_{b}} \cdot 100 .
$$

Here $A_{b}$ is the absorbance of the control reaction, and $A_{a}$ is the absorbance in the presence of the compounds. Each experiment was repeated three times.

\section{Ferric reducing antioxidant power assay (FRAP)}

Reducing properties were investigated using the FRAP method, which is based on the reduction of a ferric-tripyridyl triazine complex to its ferrous coloured form in the presence of antioxidants [19]. The FRAP reagent contained $2.5 \mathrm{~mL}$ of a $10 \mathrm{mM}$ TPTZ (2,4,6-tripyridyl-s-triazine) solution in $40 \mathrm{mM} \mathrm{HCl}$, also $2.5 \mathrm{ml}$ of $\mathrm{FeCl}_{3}(20 \mathrm{mM})$ and $25 \mathrm{ml}$ of acetate buffer $(0.3 \mathrm{M}, \mathrm{pH}=3.6)$. $100 \mu \mathrm{L}$ of the tested compounds $(5 \mathrm{mM})$ were mixed with $3 \mathrm{~mL}$ of the FRAP reagent. Afterwards, the reaction mixture was incubated at $37^{\circ} \mathrm{C}$. After $24 \mathrm{~h}$, the absorbance of the reaction mixture at $593 \mathrm{~nm}$ was measured spectrophotometrically. For comprising of the calibration curve, five concentrations of $\mathrm{FeSO}_{4} \cdot 7 \mathrm{H}_{2} \mathrm{O}(5,10,15,20,25 \mu \mathrm{M})$ were used and the absorbances were measured as a sample solution [20]. Each experiment was repeated three times.

\section{RESULTS AND DISCUSSION}

A series of carbazole-based derivatives have been designed and synthesized (Scheme, Table 1), and their antibacterial activity was evaluated against Bacillus subtilis and Escherichia coli. Various functional 


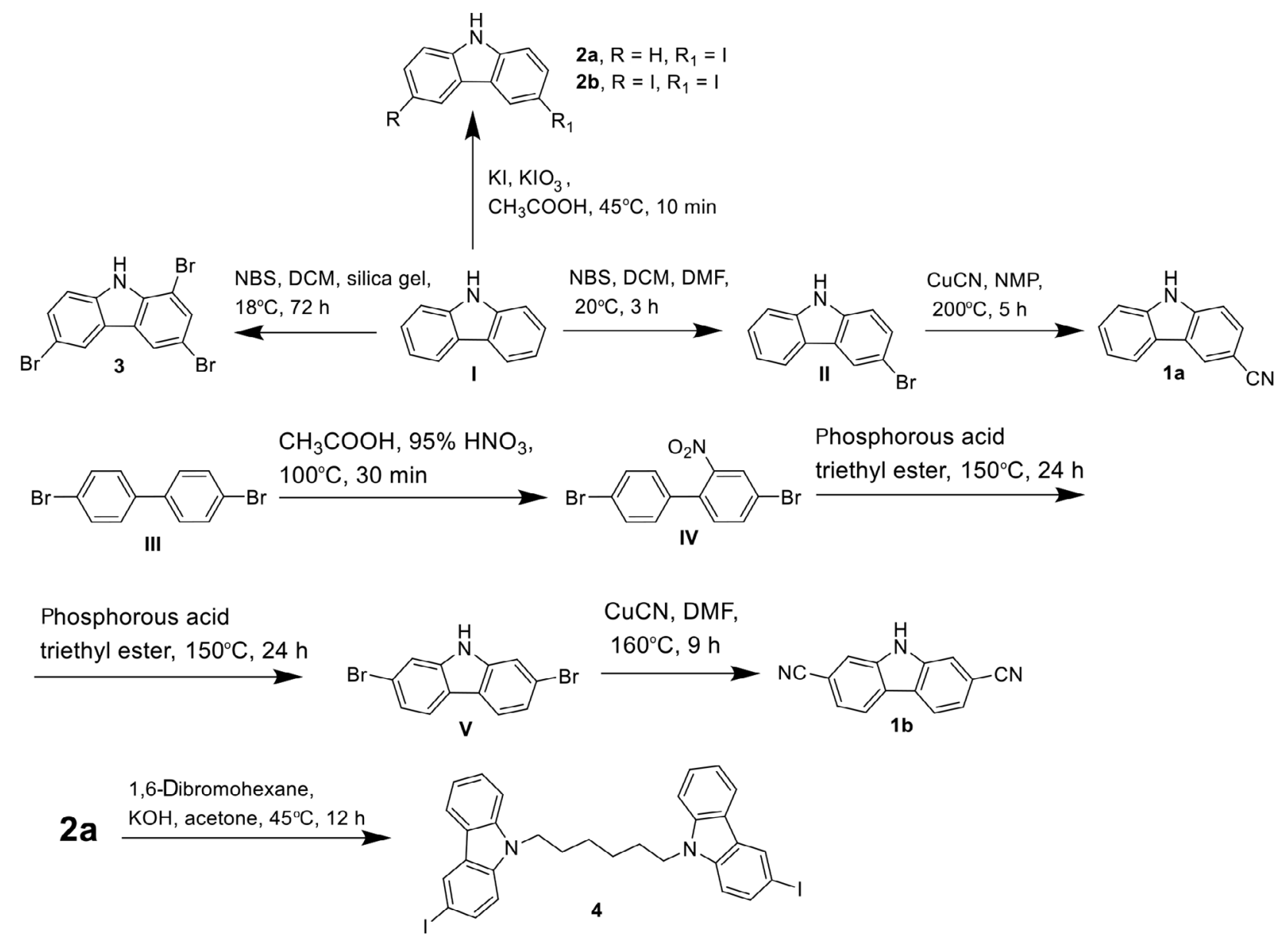

Scheme. Synthetic routes to compounds $1 \mathrm{a}-\mathbf{4}$

groups were introduced into carbazole-based compounds in order to investigate their biological activity.

Under the standard reaction conditions, when the mixture of II, CuCN in NMP was stirred in air at $155^{\circ} \mathrm{C}$ for $22 \mathrm{~h}, 3$-cyano- $9 \mathrm{H}$-carbazole (1a) was isolated in $30 \%$ yield. The reaction of dibromide $\mathbf{V}$ with $\mathrm{CuCN}$ in $\mathrm{DMF}$ gave 2,7-dicyano-9H-carbazole (1b) within $9 \mathrm{~h}$. Other materials 3-iodo- $9 \mathrm{H}$ carbazole (2a) and 3,6-diiodo-9H-carbazole (2b) were synthesized from commercially available $9 \mathrm{H}$ carbazole (I) by Tucker iodination with $\mathrm{KI} / \mathrm{KIO}_{3}$ in acetic acid. Production of 1,3,6-tribromo- $9 \mathrm{H}$ carbazole (3) provided a simple and clean synthesis of $9 \mathrm{H}$-carbazole (I) by use of three equivalents of NBS/silica. 9,9'-(Hexane-1,6-diyl)bis(3-iodo-9Hcarbazole) (4) was synthesized by the alkylation reaction with an excess amount of 1,6-dibromohexane in acetone. All derivatives (1a, $\mathbf{1 b}, \mathbf{2} \mathbf{a}, \mathbf{2} \mathbf{b}, \mathbf{3}$ and 4) were characterized by using ${ }^{1} \mathrm{H} \mathrm{NMR},{ }^{13} \mathrm{C}$ NMR spectroscopies and mass spectrometry.
Compounds 1a-5 were evaluated for their antibacterial activity against the strains of Bacillus subtilis and Escherchia coli by the disk diffusion method. The antibacterial activity of the tested compounds was compared with the activity of the known antibiotics - amoxicillin, $62.50 \mu \mathrm{g} / \mathrm{ml}(171.1 \mu \mathrm{M})$ and ciprofloxacin, $3.90 \mu \mathrm{g} / \mathrm{ml}(11.8 \mu \mathrm{M})$.

Carbazole-based compounds $\mathbf{1 a}, \mathbf{2} \mathbf{a}$ and $\mathbf{2 b}$ were the most active against Gram-positive Bacillus subtilis, they showed inhibitory activity at $31.25 \mu \mathrm{g} / \mathrm{ml}$ $(162.6,106.6,74.6 \mu \mathrm{M})$ (Table 2). These compounds showed a greater activity than that of amoxicillin, which was active only at $62.5 \mu \mathrm{g} / \mathrm{ml}(171.1 \mu \mathrm{M})$. Brominated carbazole compound 3 was slightly less active, $62.5 \mu \mathrm{g} / \mathrm{ml}(154.8 \mu \mathrm{M})$, but still comparable to amoxicillin. Against Gram-negative Escherichia coli strains the selected compounds were slightly less active, but still showed good results. Three $-\mathrm{Br}$ groups containing carbazole compound 3 were the most active at $31.25 \mu \mathrm{g} / \mathrm{ml}$ $(77.4 \mu \mathrm{M})$, it showed a greater activity than that of 
Table 1. Structures of the carbazolyl fragment containing compounds $1 \mathrm{a}-5$

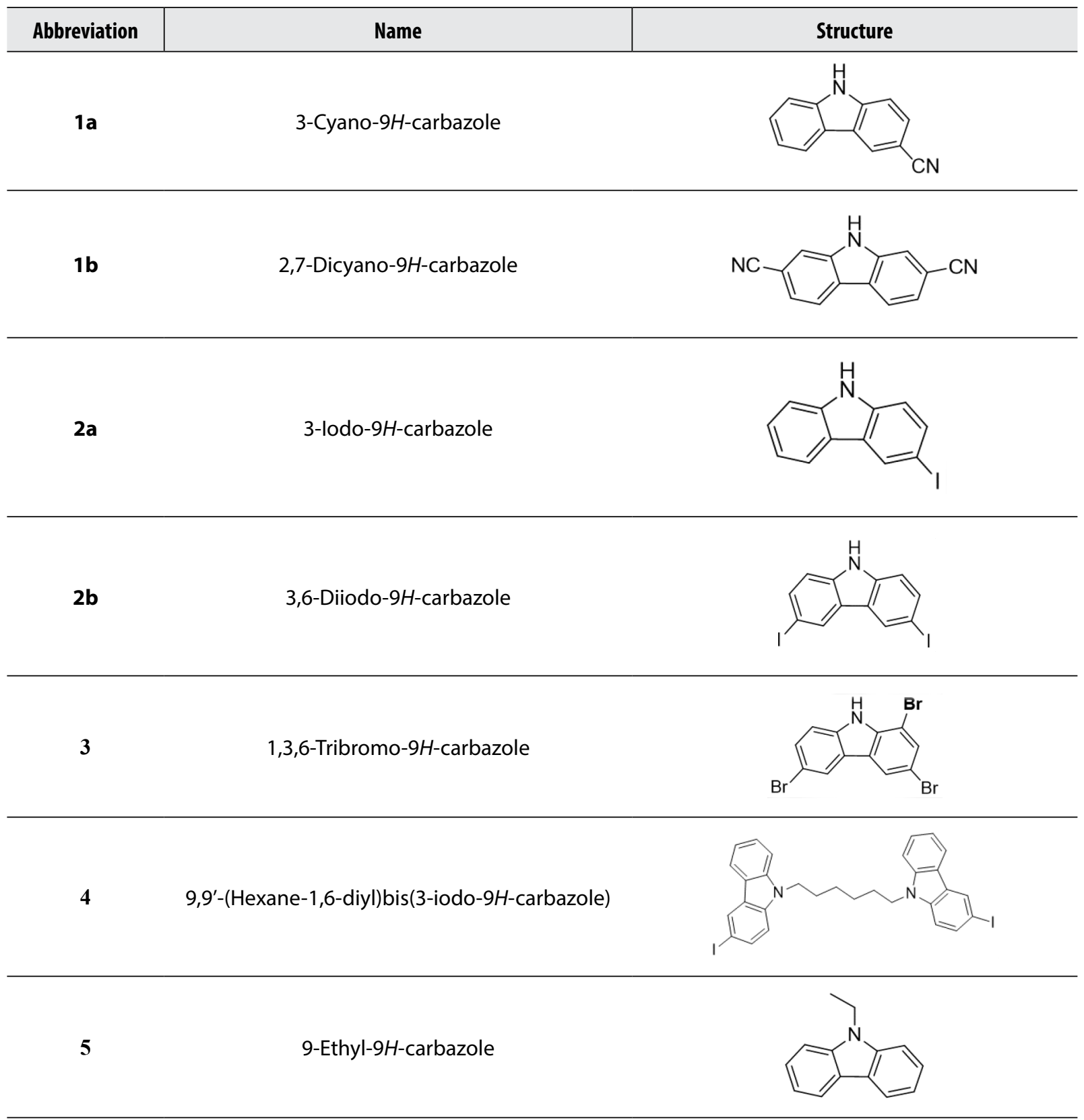

amoxicillin $62.5 \mu \mathrm{g} / \mathrm{ml}(171.1 \mu \mathrm{M})$. Compounds 2a and $\mathbf{2 b}$ were not as active as against Bacillus subtilis, but still comparable to amoxicillin and showed activity at $62.5 \mu \mathrm{g} / \mathrm{ml}(213.2,149.2 \mu \mathrm{M})$. Ciprofloxacin suppressed the growth of tested bacteria at $3.9 \mu \mathrm{g} / \mathrm{ml}(11.8 \mu \mathrm{M})$.

Evaluation of the antibacterial activity revealed that $-\mathrm{Br},-\mathrm{CN}$ and $-\mathrm{I}$ groups introduced into various carbazole ring positions determined its antibacterial activity. We can see that - $\mathrm{Br}$ carbazole compound 3 had a greater activity against Gram-negative, Escherichia coli, and -I groups containing carbazole compounds $\mathbf{2} \mathbf{a}$ and $\mathbf{2} \mathbf{b}$ showed better results against Gram-positive, Bacillus subtilis, strains. Interest- ingly, compound 1a containing only one - $\mathrm{CN}$ group at the $\mathrm{C}-3$ position showed a significant inhibitory activity against both tested bacteria, whereas compound $\mathbf{1 b}$ containing two $-\mathrm{CN}$ groups at $\mathrm{C}-2$ and C-7 positions, showed a very weak activity. This suggests that the substitutes introduced into C-3 and C- 6 positions have a greater influence on antibacterial properties than the substitutes introduced into $\mathrm{C}-2$ and $\mathrm{C}-7$ positions. This tendency has also been observed among isopropanol-conjugated carbazole azole derivatives [6]. They noted that the $-\mathrm{Br}$ substitute at the carbazole C-3 position had a greater antibacterial activity than that of the - $\mathrm{Br}$ substitute at the C-2 position containing carbazole [6]. 
Table 2. Minimum inhibitory concentration (MIC) values of the synthesized compounds against Bacillus subtilis and Escherichia coli strains

\begin{tabular}{|c|c|c|c|c|}
\hline \multirow[b]{2}{*}{ Compound } & \multicolumn{2}{|c|}{ Bacillus subtilis } & \multicolumn{2}{|c|}{ Escherichia coli } \\
\hline & $M I C, \mu g / m I(\mu M)$ & $\begin{array}{l}\text { Zone of inhibition } \\
\text { at MIC value, } \mathrm{mm}\end{array}$ & $M I C, \mu g / m I(\mu M)$ & $\begin{array}{l}\text { Zone of inhibition } \\
\text { at MIC value, } \mathrm{mm}\end{array}$ \\
\hline $1 a$ & $31.25(162.6)$ & 5.3 & $125(650.3)$ & 6.30 \\
\hline $1 b$ & $1000(4603.6)$ & 9.50 & 1000 (4603.6) & 9.67 \\
\hline $2 a$ & $31.25(106.6)$ & 5.47 & $62.5(213.2)$ & 6.17 \\
\hline $2 b$ & $31.25(74.6)$ & 6.33 & $62.5(149.2)$ & 6.00 \\
\hline 3 & $62.5(154.8)$ & 7.40 & 31.25 (77.4) & 5.95 \\
\hline 4 & $125(181.6)$ & 7.15 & $1000(1496.3)$ & 7.75 \\
\hline 5 & NA & NA & NA & NA \\
\hline Amoxicillin & $62.5(171.1)$ & 6.67 & $62.5(171.1)$ & 6.80 \\
\hline Ciprofloxacin & $3.90(11.8)$ & 7.90 & $3.90(11.8)$ & 7.40 \\
\hline
\end{tabular}

DMSO for negative control, NA for no inhibitory activity.

It should also be noted that compound 4 containing two 3-iodo-9H-carbazolyl fragments showed a weaker activity than that of compound $2 \mathrm{a}$, made of only a 3-iodo-9H-carbazolyl fragment. Also, compound 5, consisting of an ethyl group at the C-9 position, did not show any antibacterial activity against the tested bacteria. This could suggest that introducing alkyl or other closed form structures has a negative effect on antibacterial properties.

Antioxidant activities of compounds 1a-5 were evaluated using the (1,1-diphenyl-2-picrylhy-drazyl) (DPPH) radical scavenging method (Fig. 2) and the ferric reducing antioxidant power (FRAP) assay (Fig. 3).

The DPPH assay method is based on the reduction of DPPH. When a free radical DPPH meets with a hydrogen donor, it is reduced to the DPPHH therefore the free radical DPPH which has purple colour is decolourized to yellow. Measuring this change absorption at $517 \mathrm{~nm}$ allows the calculations of antioxidant activity [21].

As seen from the results presented in Fig. 2, 5 out of 7 compounds showed weak to moderate $\mathrm{DPPH}$ radical scavenging properties. The best

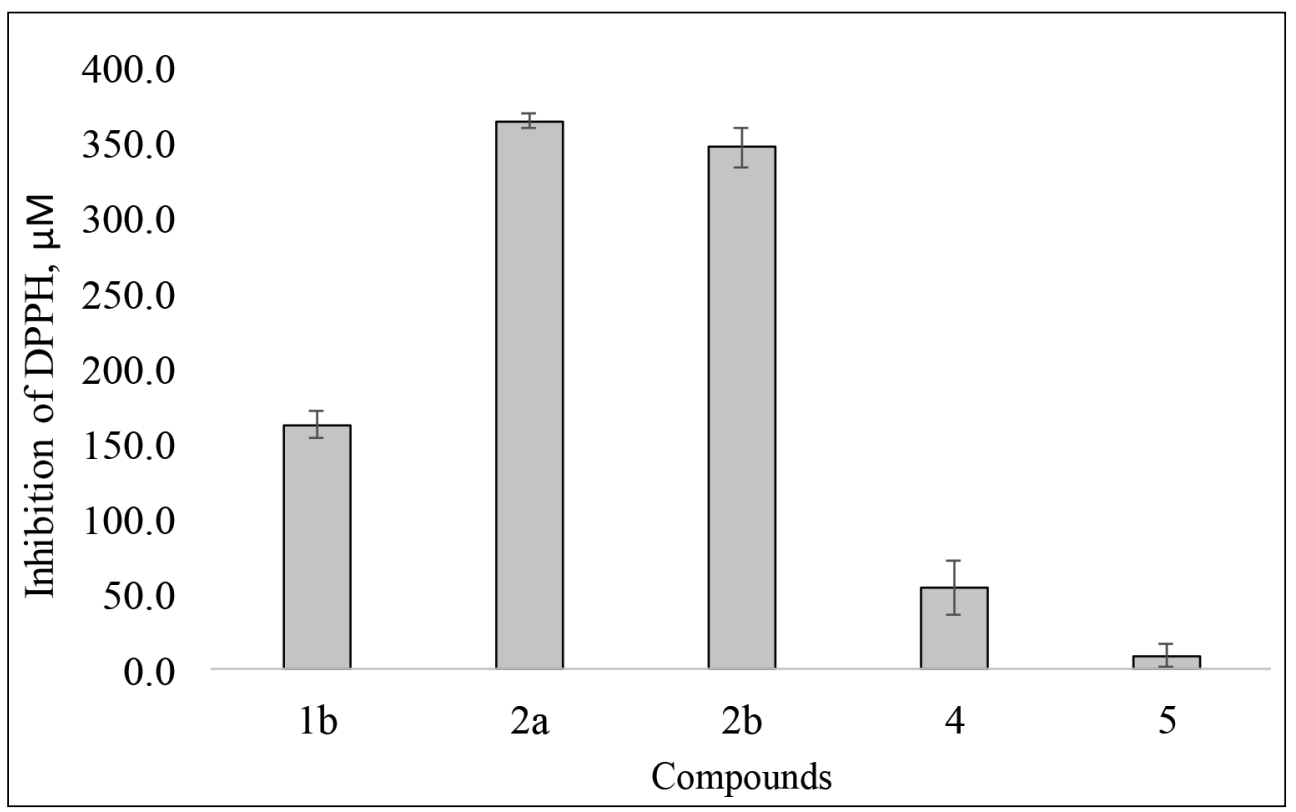

Fig. 2. DPPH radical scavenging properties of compounds $\mathbf{1} \mathbf{b}-\mathbf{2} \mathbf{b}, \mathbf{4}-\mathbf{5}$ 


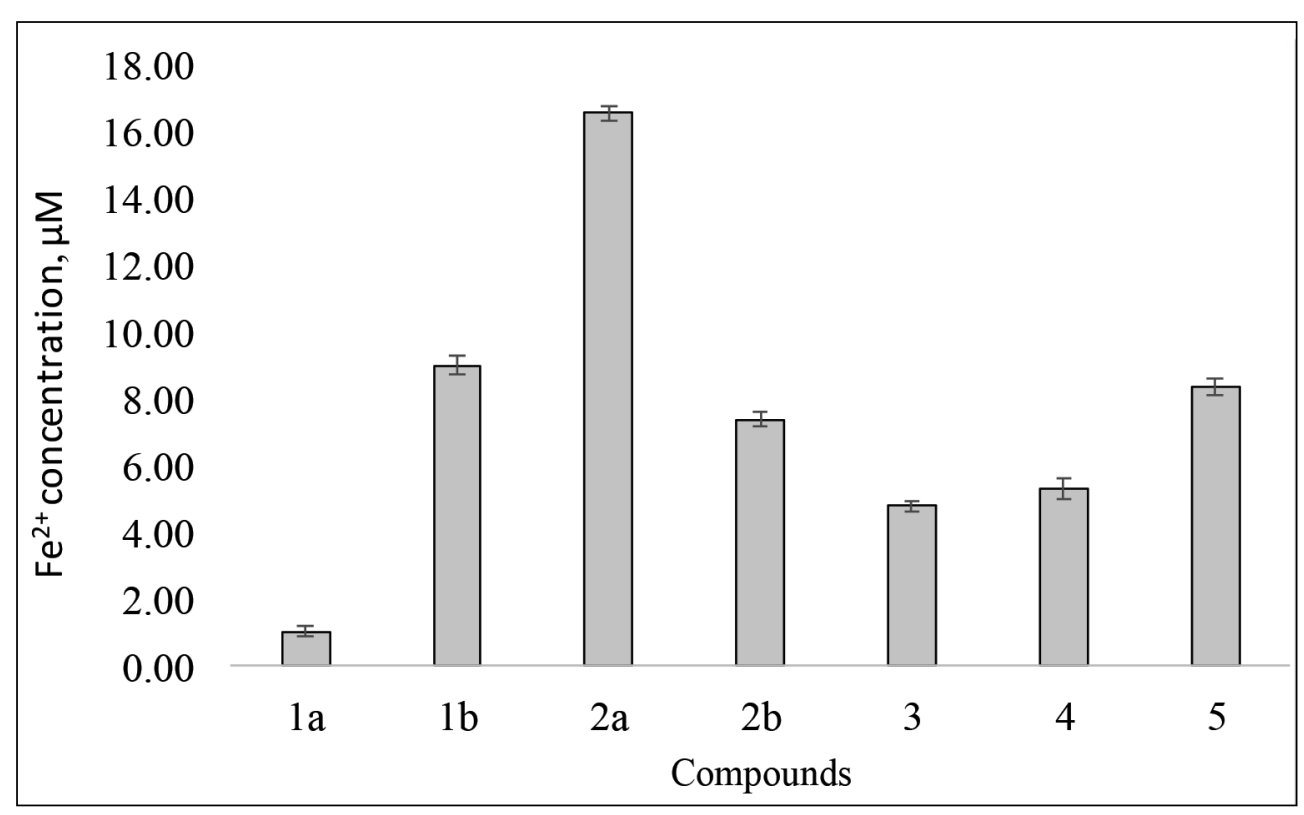

Fig. 3. Antioxidant activity of compounds $\mathbf{1 a}-\mathbf{5}$ according to the FRAP method

antioxidative activity was shown by ascorbic acid $(797.57 \mu \mathrm{M})$, which was used as standard. Standard moderate radical scavenging abilities were shown by compounds $2 \mathbf{a}(365.64 \mu \mathrm{M})$ and $\mathbf{2 b}$ $(348.02 \mu \mathrm{M})$, containing one and two -I atoms at $\mathrm{C} 3$ and $\mathrm{C} 6$ carbazole positions. Two $-\mathrm{CN}$ groups containing compound $\mathbf{1 b}$ showed two times weaker activity, at $163.00 \mu \mathrm{M}$, whereas compound 1a with only one - $\mathrm{CN}$ group showed no radical scavenging activity at the tested concentration. Compound 5, with an introduced ethyl substitute at the C9 position, and two 3-iodo-9H-carbazolyl fragments containing compound 4 showed weak radical scavenging abilities, $9.53 \mu \mathrm{M}$ and $54.33 \mu \mathrm{M}$, respectively. Compound 3, containing three $-\mathrm{Br}$ atoms, showed no antioxidative activity.

The radical scavenging activities of compounds 1a-5 may be attributed to the electronic effects of substituent groups on the carbazole scaffold and the free $-\mathrm{NH}$ group at the $\mathrm{C} 9$ carbazole position. The importance of the free -NH group can be seen between compound 2a, containing one -I atom at the $\mathrm{C} 3$ position, which showed the best radical scavenging ability, and compound 4 , containing two 3-iodo-9H-carbazolyl fragments and no free -NH group, which showed a lot weaker radical scavenging activity.

The FRAP method is based on electron transfer rather than hydrogen atom transfer [17]. The method is based on the ability of an antioxidant to reduce the $\mathrm{Fe}^{3+}$ complex with 2,4,6-trypyri- dyl-s-triazine $\left(\mathrm{Fe}(\mathrm{TPTZ})^{3+}\right)$ to the $\mathrm{Fe}^{2+}$ complex $\left(\mathrm{Fe}(\mathrm{TPTZ})^{2+}\right)$ [22]. The increase in absorbance of the intensely blue coloured $\mathrm{Fe}^{2+}$ complex is measured at $593 \mathrm{~nm}$ and results can be expressed as $\mathrm{Fe}^{2+}$ concentration $(\mu \mathrm{M})$.

The results, shown in Fig. 3, revealed that compared to ascorbic acid $(115.67 \mu \mathrm{M})$, which was used as standard, all tested compounds showed a weak activity to reduce $\mathrm{Fe}(\mathrm{TPTZ})^{3+}$ to $\mathrm{Fe}(\mathrm{TPTZ})^{2+}$. Out of the tested compounds, compound $\mathbf{2 a}$, containing one -I atom, at the C3 carbazole ring position, showed a notably higher ability $(16.60 \mu \mathrm{M})$ to reduce $\mathrm{Fe}(\mathrm{TPTZ})^{3+}$. Compounds $\mathbf{1 b}, \mathbf{2 b}, \mathbf{3}, \mathbf{4}$ and $\mathbf{5}$ showed similar results (4.80-9.02 $\mu \mathrm{M})$. Lastly, only at $1.05 \mu \mathrm{M}$, compound 1a showed the weakest antioxidant activity according to the FRAP assay.

Even though the literature review revealed that good reductive properties were shown by carbazoles containing - $\mathrm{OH}$ [23], $-\mathrm{NO}_{2}$ and $\mathrm{OCH}_{3}$ [24], the ability to reduce $\mathrm{Fe}(\mathrm{TPTZ})^{3+}$ to $\mathrm{Fe}(\mathrm{TPTZ})^{2+}$ of the tested compounds $\mathbf{1 a}-\mathbf{5}$ can also be related to the electronic effects of substituent groups and the redox properties of these compounds.

\section{CONCLUSIONS}

In summary, various mono-, di- and tri-substituted carbazole derivatives, containing appropriate halogens, cyano and alkyl groups, were synthesized. Screening of their antibacterial activity has displayed that against Bacillus subtilis the most 
active antibacterial agents were 3-cyano-9H-carbazole, 3-iodo-9H-carbazole and 3,6-diiodo- $9 H$ carbazole, they suppressed the growth of bacteria at a concentration of $31.25 \mu \mathrm{g} / \mathrm{ml}(162.6,106.6$, $74.6 \mu \mathrm{M})$. Escherichia coli bacteria were the most sensitive to 1,3,6-tribromo-9H-carbazole, which inhibited their growth at a concentration of $31.25 \mu \mathrm{g} / \mathrm{ml}(77.4 \mu \mathrm{M})$. The antibacterial activity assay also revealed that the carbazole derivatives substituted at C-3 and C-6 positions displayed better antibacterial activities than the carbazoles substituted at C-2 and C-7 positions. Also, it should be noted that the carbazoles containing -I substitutes better suppressed the growth of Grampositive bacteria and the $-\mathrm{Br}$ containing carbazole better inhibited the growth of Gram-negative bacteria. The antioxidant activity assay revealed that the tested compounds displayed weak to moderate radical scavenging properties according to the 1,1-diphenyl-2-picryl-hydrazyl method and weak reductive properties according to the ferric reducing antioxidant power method, resulting in that $\mathrm{CN},-\mathrm{Br}$ and $-\mathrm{I}$ substitutes introduced into carbazole did not determine good radical scavenging and reducing properties.

\section{ACKNOWLEDGEMENTS}

This research was supported by the Research, Development and Innovation Fund of Kaunas University of Technology and the Research Fund of Lithuanian University of Health Sciences/The Research, Development and Innovation Fund of Vytautas Magnus University (SLOPSINT). We are grateful to Dr. Eigirdas Skuodis and Dr. Gintare Krucaite for the provided compounds.

Received 19 November 2019 Accepted 10 December 2020

\section{References}

1. S. T. Cole, Philos. Trans. R. Soc. Lond. B Biol. Sci., 369, 1 (2014).

2. T. Indumathi, T. Brant, M. Zeller, K. J. R. Prassad, Indian J. Chem., 52B, 405 (2013).

3. S. Chakraborty, B. Chakraborty, A. Saha, et al., Indian J. Chem., 56B, 701 (2017).

4. Z. Yang, Y. Chen, G. Li, et al., Chem. Eur. J., 24, 6087 (2018).
5. G. M. Ziarani, R. Moradi, N. Lashgari, G. H Kruger, Metal-Free Synthetic Organic Dyes, Elsevier, 109 (2018).

6. F. Zhang, L. L. Gan, C. H. Zhou, Bioorg. Med. Chem. Lett., 20, 1881 (2010).

7. Y. J. Eun, M. H. Foss, D. Kiekebusch, et al., J. Am. Chem. Soc., 134(28), 11322 (2012).

8. J. D. D. Pitout, Expert Rev. Anti Infect. Ther., 10(10), 1165 (2012).

9. Y. Zhang, V. K. R. Tangadanchu, Y. Cheng, et al., ACS Med. Chem. Lett., 9(3), 244 (2018).

10. E. B. Hirsch, P. C. Zucchi, A. Chen, et al., Antimicrob. Agents Chemother., 60(5), 3138 (2016).

11. E. Skuodis, A. Tomkeviciene, J. V. Grazulevicius, Dyes Pigments, 139, 795 (2017).

12. D. A. Patrick, D. W. Boykin, W. D. Wilson, Eur. J. Med. Chem., 32, 781 (1997).

13. Y. Wu, H. Guo, T. D. James, J. Zhao, J. Org. Chem., 76, 5685 (2011).

14. K. Smith, D. James, A. G. Mistry, M. R. Bye, D. J. Faulkner, Tetrahedron, 48(36), 7479 (1992).

15. R. Butkute, R. Lygaitis, V. Mimaite, et al., Dyes Pigments, 146, 425 (2017).

16. B. Bonev, J. Hooper, J. Parisot, J. Antimicrob. Chemother., 61, 1295 (2008).

17. R. C. Jagessar, A. Mars, G. Gomes, Nat. Sci., 6(2), 24 (2008).

18. K. Mishra, H. Ojha, N. K. Chaudhury, Food Chem., 130, 1036 (2012).

19. R. L. Prior, X. Wu, K. Schaich, J. Agric. Food Chem., 53, 4290 (2005).

20. D. Huang, B. Ou, R. L. Prior, J. Agric. Food Chem., 53, 1841 (2005).

21. T. C. Shekhar, G. Anju, A. J. Ethno., 1(4), 244 (2014).

22. L. Cerretani, A. Bendini, in: V. R. Preedy, R. R. Watson (eds.), Olives and Olive Oil in Health and Disease Prevention: Rapid Assays to Evaluate the Antioxidant Capacity of Phenols in Virgin Olive Oil, Academic Press (2010).

23. U. Songsiang, T. Thongthoom, P. Zeekpudsa, et al., ScienceAsia, 38, 75 (2012).

24. T. Taj, R. R. Kamble, T. M. Girresh, et al., Eur. J. Med. Chem., 46, 4366 (2011). 
Kęstutis Dabrovolskas, Ilona Jonuškienė, Simona

Sutkuvienė, Dalius Gudeika

\section{KARBAZOLO DARINIŲ SINTEZE் BEI JŲ ANTIBAKTERINIŲ IR ANTIOKSIDACINIŲ SAVYBIUQ VERTINIMAS}

Santrauka

Pagal žinomus metodus buvo susintetinti septyni junginiai ir, taikant diskelių difuzijos metodą, ištirtos jų antibakterinès savybės dviems bakterijoms (Bacillus subtilis ir Escherichia coli). Antioksidacinès savybès buvo nustatytos remiantis laisvųjų 1,1-difenil-2-pikrilhidrazilo radikalų sugaudymo ir geležies jonų redukcijos antioksidacinio aktyvumo nustatymo metodais. Diskelių difuzijos metodu buvo nustatyta, kad šeši iš septynių junginių turèjo antibakterini poveiki tirtoms bakterijoms ir jų augimą slopino esant ịvairioms junginių koncentracijoms - nuo 31,25 iki $250 \mu \mathrm{g} / \mathrm{ml}$. Bacillus subtilis bakterijas stipriau veike 3-ciano-9H-karbazolas, 3-jod-9Hkarbazolas ir 3,6-dijod-9H-karbazolas, o Echerichia coli bakterijas - 1,3,6-tribrom-9H-karbazolas, palyginti su amoksicilinu. Tirti junginiai pasižymèjo silpnomis vidutinėmis radikalų sugaudymo savybėmis, kai buvo taikytas 1-difenil-2-pikrilhidrazilo laisvųjų radikalų sugaudymo metodas, ir silpnomis redukcinemis savybėmis taikant geležies jonų redukcijos antioksidacinio aktyvumo nustatymo metodą. 